\title{
Relation between the Ottoman Empire and the Johor Sultanate: Perception and Influence
}

\section{Ermy Azziaty Rozali}

\author{
Universiti Kebangsaan Malaysia; Email: ermy@ukm.edu.my
}

Wan Kamal Mujani

Universiti Kebangsaan Malaysia; Email : inawan@ukm.edu.my

Azmul Fahimi Kamaruzaman

Universiti Kebangsaan Malaysia; Email: azmul@ukm.edu.my

Doi:10.5901/mjss.2016.v7n2s1p405

\begin{abstract}
The relationship between the Malay World and the Middle East, including Ottoman Empire is a very interesting subject to discuss. The said region became an attention to the Malay society to gain education and knowledge as well as claiming experience in reform movement and the expansion of politics. This paper work will discuss the relationship between Ottoman Empire and Johor Sultanate. As the last empire that accepts the British Resident, Johor Sultanate had been seen as the Malay Empire that has the strength of its own especially during the Sultan Abu Bakar's reign. The relationship between Ottoman Empire and Johor Sultanate starts during Sultan Abu Bakar's reign when he visited Istanbul on his way to visit Europe. As the result of the connection between these two empires, it can be seen that Ottoman Empire were given respect as they were the capital of an Islamic empire. The thought flourish and became an influence to the community of Malay of Johor and can be identified through the poems such as 'Syair Sultan Abu Bakar' and 'Syair Almarhum Baginda Sultan Abu Bakar in Johor State' as well as the introduction to Majalah Ahkam Johore.
\end{abstract}

\section{Introduction}

The Malay people have the perception that shows the tendency of giving respect towards the dawlah Ottoman Empire. That perception and the tendency mainly stated and can be detected in the traditional Malay literary works (Amongst the traditional Malay literary works that being referred to study the perception and the relationship between the Malay people and Ottoman Empire were Hikayat Merong Mahawangsa, Hikayat Aceh, Hikayat Perang Setambul, Hikayat Peperangan al-Maulana Sultan Istanbul dan Yang Bernama Abdul Hamid Khan Ibni Almarhum Al-Maulana Abdul Majid Khan Ghazi Dengan Raja Rushin Yang Bernama Francis Alexander, Hikayat Hang Tuah and Syair Sultan Abu Bakar.). This can be seen through the effort of relating the Malay Sultanate genealogy with the Ottoman Empire, that can be considered as the powerful force of Islamic World during that period. The Malay people were also concerned with the development that occurred within the said dawlah, highlighting from $19^{\text {th }}$ century until $20^{\text {th }}$ century. The traditional Malay literary works were also influenced by the Middle East and Central Asia, referring to the Rome Empire and Ottoman Empire (Milner, 2004). The influence brought by the Ottoman Empire can be traced among the Malay people through the propagation of PanIslamism that instill awareness towards the British colonialism and the propagation was highly supported by the dawlah himself (Ozcan, 1994).

Istanbul, aside from Mecca and Medina, which is known as the early knowledge center for Muslims and also for the Malay people, became another destination for the pursuit of knowledge and for the diplomatic relations bonding. The beginning of the relationship between the Malay people and Ottoman Empire were identified during the visit of Johor Sultanate, which was Sultan Abu Bakar (1862-1895) to Istanbul in 1879 and 1893 (Mohamed, 2000). Sultan Abdul Hamid II (1876-1909) which was the Sultan for the Ottoman Empire during that period, conferred the First Class of Uthmanli to the Sultan Abu Bakar during his visit to Istanbul in 1893 (Isa, 1982). Sultan Abu Bakar dropped by in Cairo, Egypt, before continued his visit to Istanbul. Wilfred Blunt introduces His Majesty to Shaykh al-Bakri, whom was one of the PanIslamism followers. During that encounter, Shaykh al-Bakri wished to know whether Sultan Abu Bakar was interested with the concept of Pan-Islamism or to place the missionaries of Pan-Islamism in Johor.

As an answer to the question from Shaykh al-Bakri, Sultan Abu Bakar explained to him carefully that he himself 
was one of the small Malay Empire leaders and there was nothing important for him to discuss with the Sultan of Ottoman Empire. Sultan Abu Bakar would gladly accept the entrance of the missionaries that could give the education on Islamic teaching to the people of Johor. He explained that his people rather followed the sect of Syafii and for the fact that they were unskilled in Arabic Language. Although we can see that there was a close relationship between Johor Sultanate and Ottoman Empire, Sultan Abu Bakar seemed not to put any interest with the concept of Pan-Islamism (Gullick, 1992). Therefore, the Malay people took notice of the Pan-Islamism concept through their leader's connection with the famous figures and leaders of Ottoman Empire.

\section{Relationship between Ottoman Empire and the Johor Sultanate}

To reveal the relationship between Ottoman Empire with the Malay people, this paper will review on the perception of the Malay people towards the said dawlah through the literary works. The Malay people shows their appreciation through the poem, 'Syair Sultan Abu Bakar' (Basri, 1983; Isa, 1982). Joseph H. Howard had listed the Malay literary works in his book, The Malay Manuscript and give evidence on 'Syair Sultan Abu Bakar'. There was a poem about Sultan Abu Bakar bin Sultan Ibrahim of Johor in Howard's note with 90 pages long (Howard, 1966). The poem was named as 'Syair Sultan Abu Bakar' (Hussein, 1976). There were poem, verse as well as Gurindam in the Malay literary writings that are concerned with the historical events that had happened. The historical events were the common genre in the Malay literary writings (Kim \& Mohd Fadzil, 1980).

It has two versions and one of the versions was written in Jawi and compiled in a copy. There was no difference in narration and contents between the two versions. Therefore it can be considered that there was only one copy and the emerged second version was in the form of lithographic and the latter was in the form oforthography hand. These two versions tells that this poem was completely written in 1899, and a year after that, it was been lithographed by $\mathrm{Hj}$. Muhammad Amin Printing, Lorong Dalam, Kampung Kecil, Singapura. The manuscript of this poem was kept in National University Singapore and School of Oriental and African Studies, London (Proudfoot, 1993).

This poem has less attraction towards the researcher, but it has been converted to the usual Malay form of writings and has been published for two times. In 1982, the Museum Board of Pahang published the monograph entitled 'Beberapa Aspek Sejarah dan Kebudayaan Negeri Pahang'. It was included with a poem entitled 'Syair Tanah Melayu, iaitu Cerita Perang Pahang dan Johor Baharu' and it was converted to the conventional form of writing by Yaakub bin Isa (Isa, 1982). In 1983, through his book entitled 'Sejarah Warisan Johor' he managed the poem 'Syair Sultan Abu Bakar' with his own annotation (Basri, 1983).

This poem reflects on the political situation in Johor, especially during the reign of Sultan Abu Bakar and the turmoil of civil war that happened in Pahang. His Majesty had always having diplomatically relationship with the other country. This good relationship was proven when there was a visit from the other country such as the visit of Duke of Sutherland and The King of Itali. His Majesty was awarded with many titles as a symbol of friendship such as from The King of Germany, The King of Italy, The King of Russia and The Queen of British. His Majesty had been to Istanbul, the capital city of Ottoman Empire (Md Nor, 2000).

The story during his visit to Istanbul of Ottoman Empire had been narrated at length in this poem. His arrival in Istanbul receiving friendly treatment from Sultan Abdul Hamid II. The poet describes the grandeur of Ottoman Empire that attracts the attention of Sultan Abu Bakar and also the government officials that happened to be the escorts. His Majesty visited the palace, the city and the village. It had been stated in the poem about the infrastructure that the Ottoman Empire had such as roads, markets and also the advancement of the defense equipment.

The adulations towards the wealth and economic stability of Ottoman Empire that was formed by the sagacity in the Sultan's administrative happened to be explained in this poem. Apart from that, the tax from the country under the auspices of Ottoman Empire also generates the economic resources and the wealth of the country. As a leader of the country, Sultan Abdul Hamid II was having a lot of diplomatic relations with the other country. His majesty's generosity clearly described in the verses of the poem as he gave the special title for friendship purpose to the country that has the relationship with Ottoman Empire. At the end of the visit, Sultan Abu Bakar was awarded with the title of Uthmanli; while His Majesty's escort, Haji Kassim was awarded with the title of Majidi.

The relationship between the Johor Sultanate and Ottoman Empire starts when Sultan Abu Bakar made his visit in 1879 and 1893 had been reflected through the poem 'Syair Sultan Abu Bakar'. During the visit Sultan Abdul Hamid II had awarded His Majesty with the first class title of Ottoman Empire (Adil, 1980). The good relations between Johor Sultanate-Ottoman Empire had impacted Johor as the Johor Bharu city was thought as the twin city of Istanbul (Borham, 2000).

Sultan Abu Bakar died in London on $4^{\text {th }}$ June 1895 (Hussain, 1994). The people of Ottoman Empire were informed 
of the news of His Majesty's death. Dato's Seri Amar Diraja Abdul Rahman bin Andak along with Mr. Block, the British Embassy officials in Istanbul facing the Sultan of Ottoman Empire to convey a sense of grief regarding the final meeting between the late Sultan of Johor and Sultan Abdul Hamid II which was in 1893. Sultan Abdul Hamid congratulates Sultan Ibrahim Ibni Abu Bakar for succeeding his late father and awarding him with first class Uthmanli title. Dato' Seri Amar Diraja was awarded with the second class of Uthmanli title. A ceremonial event was held Dato' Seri Amar Diraja's achievement as he received the title from Istanbul.

The influence of Ottoman Empire can be seen within the development of Islamic law in Johor. This can be detected through the usage of Majallah al-Ahkam al-Adliyyah that has been used in Ottoman Empire in 19th century as Majalah Ahkam Johor (Ziadeh, 1992). The magazine has been implemented since 1913 that involving the civil law (Borham, 1997).

In 1913, the translation effort to Bahasa Melayu has been done towards Majallah al-Ahkam al-'Adliyyah Turki Uthmaniyah. The Johor religion department was the main performer in the process of translating and implementation of Majalah Ahkam Johor. Dato' Syed Abdul Kadir Mohsin al-Attas, the Mufti of Johor and Engku Sulaiman Engku Daud, the president of the religion department of Johor was the people whom played a bigger role during the process (Borham, 2007: 95). According to the Law of Johor, clause of 49, the translation of the book was named as Majalah Ahkam Johor. Sultan Ibrahim Ibni Abu Bakar gave permission to Dato' Syed Abdul Kadir Mohsin al-Attas, the Mufti through the letter from Dato' Pemangku Setiausaha Kerajaan Johor, issue 998/13 with the date of $29^{\text {th }}$ November 1913. With the assent from the Sultan and according to the date of the letter indicates the starting of the usage of Majalah Ahkam Johor as the book of guidance regarding the Islamic law in Johor (Fail Majlis Agama Johor, 1934).

Apart from the Syair Sultan Abu Bakar which was written by a Peranakan Lingga, there was another poem entitled Syair Almarhum Baginda Sultan Abu Bakar di Negeri Johor. The text contain of 1400 verse, attractive content and a bit different from Syair Sultan Abu Bakar which was managed by Yaakub Isa and M.A Fawzi Basri. This poem didn't mention the political issue of Pahang and Johor, but more to the scenario of Johor and Sultan Abu Bakar as the main subject in the poem's writings (Mohamed, 2001).

$\mathrm{Na}$ Tien Piet, the poet, was a literary figure in the Peranakan Chinese literature within this region. His love and identity can be measured from the poem Syair Almarhum Baginda Sultan Abu Bakar (Mohamed, 2001). He was originated from The Dutch East India, and pose as a merchant, reporter and also as an editor of Bintang Timor newspaper. He used 'Kalam Langit' as his pseudonym. Syair Almarhum Baginda Sultan Abu Bakar has been published in Bintang Timor newspaper starting from the February edition to June 1895 edition (Ding, 2002). In the poem, it was said that the Johor Sultanate received praises from the Ottoman Empire for protecting their kingdom from the British colonization.

Syair Almarhum Baginda Sultan Abu Bakar also shows the relation with Ottoman Empire that leads to the influence towards the Johor Sultanate. It can be traced from some aspects, such as the usage of decoration in the palace, the dress code, the title and also the symbol on the flag. Syair Sultan Abu Bakar and Syair Almarhum Baginda Sultan Abu Bakar di Negeri Johor clearly shows the perception and the influence from Ottoman Empire to the Malay people. The progress and the peace gained by the people of the Ottoman Empire under the rule of Sultan Abdul Hamid II was clearly be depicted in the poem. The delivery of titles from the Ottoman Empire to the Sultan of Johor and the officials shows the closeness relationship between the two countries.

\section{Conclusion}

As a whole, it can be seen that there was a relation and the influence of the Ottoman Empire upon the Johor Sultanate and it can be detected through the Malay literary works. The initial contact was made by the Empire of Aceh with the Ottoman Empire in the $16^{\text {th }}$ century, shows the positive perception received from the Malay people towards the dawlah. It is clear that the Malay people has the outside networks of its own and creates relationships with the international community. The relationship between the Ottoman Empire and Johor Sultanate was one part of the history that juxtapose the Malay people in this region and the outside Islamic world.

\section{References}

Adil, B. (1980). History of Johore. Kuala Lumpur : Dewan Bahasa dan Pustaka.

Blunt, W. S. (1921). My Diaries Being A Personal Narrative of Events, 1888-1914. Martin Secker: London.

Borham, A. J. (1997). Majalat Ahkam Johore From the Background and Its Influence in the Adiministration of Muamalat in Johore. PhD Theses, Akademi Islam, Universiti Malaya. 
Borham, A. J. (2002). Majalah Ahkam Johore: The Background, Implementation and Feedback Johor Bharu : Penerbit Universiti Teknologi Malaysia. Kuala Lumpur: Persatuan Sejarah Malaysia.

Gullick, J. M. (1992). Rulers and Residents Influence and Power in the Malay States 1870-1920. Singapore : Oxford University Press.

H.C.O (Despatch FMS 1896-1899). "Interview Between the Sultan Turkey and the Envoy of the Sultan of Johore Forwards a Letter From Ambasaddor at Constantinople". Arkib Negara Malaysia.

Hashim, M. Y. \& Gopinath, A. (1992). Historiography Tradition Pahang Darul Makmur 1800-1930 Tradisi Pensejarahan Pahang Darul Makmur 1800-1930. Petaling Jaya: Tempo Publishing.

Howard, J.H. (1966). Malay Manuscript: A Bibliographical Guide. Kuala Lumpur: University Malaya.

Husain, S. (1994). History of Johore and its relations to the Malay States. Shah Alam: Penerbit Fajar Bakti.

Hussein, I. (1976). "Documentation: "Poetry of Sultan Abu Bakar Ibni Sultan Ibrahim Johore". Dewan Bahasa. May. Kuala Lumpur: Dewan Bahasa \& Pustaka.

Ibrahim, S. (1977). "The Administration of Islamic Law in Johore". Paper Project. Fakulti Undang-Undang. University Malaya.

Isa, Y. (1982). "Poem of Malaya, War Stories Pahang and Johor Baharu." In Mohd. Mokhtar Abu Bakar (eds) Some Aspects of the History and Culture of Pahang. Pahang in History Pekan: Lembaga Muzium Negeri Pahang.

Jaafar, O. (1935). Selamat Johore Remembrance 40th Anniversary For His Majesty the Sultan Ibrahim Reside in Johore Government's Throne. Singapura.

Khoo, K. K. \& Othman, M. F. 1980. Literature and Literary. Kuala Lumpur: Persatuan Sejarah Malaysia.

Majalat Ahkam Johore Assembly of All the Laws of Figh the issue of Islam. Muar: Matbaah al-Khairiyyah 1331H. Part of Introduction. Arkib Negara Malaysia Cawangan Johor.

Md. Nor, M. Y. (2000). "Poetry of Sultan Abu Bakar : Documentation of History of Johore". Dewan Sastera. July. Kuala Lumpur: Dewan Bahasa dan Pustaka.

Milner, A. C. (2004). "Afterword: A History of Malay Ethnicity". In Timothy P. Barnard (eds.). Contesting Malayness Malay Identity Across Boundaries. Singapore: National University Press.

Ming, D. C. (2002) "Publication of Pantun and Poetry of Chinese Baba in Malaya".. Sari, 20, 113-146.

Mohamed, A. (1971). "The Travel of Abu Bakar, Maharajah Johore to the Far East", Malaysian In History, 14(1), 3-9.

Mohamed, N. (eds.). (2001). Poetry of Sultan Abu Bakar in State of Johore Johor Bharu: Yayasan Warisan Johor.

Mohammad Rasdi, M. T. (2009). "Interpretation problems Mosque Architecture Idea from the Perspective of the Western Historiography". In Kulthum Ibrahim et.al (eds.). The Malay and Islamic World Discourse, Institut Alam dan Tamadun Melayu UKM: Bangi.

Mohd Adnan, H. (1998). Publishing and Printing Books Literature 1807-1960. Kuala Lumpur: Dewan Bahasa \& Pustaka.

Mohd Noor, A. (2006). History and Historiography. Kuala Lumpur: Dewan Bahasa dan Pustaka.

Othman, M. R. (1996). "Pan-Islamic Appeal and Political Patronage: The Malay Perspective and the Ottoman Response". Sejarah, 4, 97-108.

Proudfoot, I. (1993). Early Malay Printed Books Books: A Provisional Account of Material Published in the Singapore-Malaysia Area up to 1920, Noting Holdings in Major Public Collections. Kuala Lumpur: Akademi Pengajian Melayu dan Perpustakaan Universiti Malaya.

Reid, A. (1967). "Nineteenth Century Pan-Islam in Indonesia and Malaysia". Journal of Asian Studies, 26(2), 267-283.

Ziadeh, F. J. (1979). Property Law in the Arab World Real Rights in Egypt, Iraq, Jordan, Lebanon, Libya, Syria, Saudi Arabia and the Gulf State. London: Graham and Trotman. 